흑백 사진의 재질 분석

- 보로부두르 사진을 중심으로 -

\title{
Material Analysis of Black and White Photograph - Photograph from Borobudur -
}

\author{
윤은영, ${ }^{1}$, Modhamad $\mathrm{Habibi}^{2}$, 진홍주 ${ }^{1}$ \\ ${ }^{1}$ 국립문화재연구소 보존과학연구실, ${ }^{2}$ 인도네시아 문화교육부 보로부두르 보존처리소 \\ Eun Young Yun ${ }^{1,{ }^{*}}$, Modhamad Habibi ${ }^{2}$, Hong Ju Jin ${ }^{1}$ \\ ${ }^{1}$ Conservation Science Division, National Research Institute of Cultural Heritage, Daejeon 34122, Korea \\ ${ }^{2}$ Borobudur Conservation Office, Ministry of Education and Culture, Magelang, Central Java 56553, Indonesia
}

Received November 03, 2018 Revised December 10, 2018

Accepted September 10, 2019

*Corresponding author

E-mail: dalsan81@korea.kr

Phone: +82-42-860-9251

Journal of Conservation Science

2019;35(5):385-391

https://doi.org/10.12654/JCS.2019. 35.5.01

pISSN: 1225-5459, eISSN: 2287-9781

(c) The Korean Society of Conservation Science for Cultural Heritage

This is an Open-Access article distributed under the terms of the Creative Commons Attribution Non-Commercial License (http://creativecommons.org/ licenses/by-nc/3.0) which permits unrestricted non-commercial use, distribution, and reproduction in any medium, provided the original work is properly cited.
초 록 인도네시아 보로부두르 보존처리소에서 촬영한 보로부두르 사원 흑백 사진의 재질 특성 을 조사하기 위해 과학적 분석을 수행하였다. 흑백 사진에서 시료를 채취하여 현미경 조사, 성분 및 재질 분석을 진행한 결과 흑백 사진은 지지체, 바리타층, 바인더층, 표면층 등 4 개의 층으로 구성되어 있는 것을 확인하였다. 지지체는 마섬유로 구성된 종이, 바리타층은 분말상태의 황산 바륨 $\left(\mathrm{BaSO}_{4}\right)$, 바인더층은 할로겐화은이 함유된 유제, 표면보호층은 젤라틴을 사용하여 제작된 것으로 판단하였다. 사진은 구성 재질에 따라 특성 및 보존 환경이 다르므로 시대에 따른 다양한 흑백 사진 재질 특성에 대한 연구가 필요하다.

\section{중심어 흑백 사진, 재질 분석, 황산바륨, 젤라틴, 할로겐화은}

ABSTRACT In order to examine the material characteristics of a black and white photograph of the Borobudur temple, in Indonesia, several analyses were conducted. A sample was taken from a black and white photograph; microscopy, Fourier transform-infrared spectroscopy, scanning electron microscopy/energy dispersive spectroscopy, X-ray diffraction, and X-ray fluorescence analyses showed that the black and white photograph was composed of four layers including a paper substrate, baryta, binder and surface layers. It was confirmed that the substrate was paper made of cellulose fiber from Cannabis sativa, the baryta layer was made of barium sulfate $\left(\mathrm{BaSO}_{4}\right)$ in powder form, the binder was an emulsion containing silver halide, and the surface protective layer was made of gelatin. Since photographs have different characteristics and require different preservation environments depending on the material of construction, it is necessary to study various black and white photographic material characteristics corresponding to each time period.

Key Words Black and white photograph, Material analyses, Barium sulfate, Gelatin, Silver halide 


\section{1. 서 론}

사진은 카메라를 사용해 물체의 형상을 감광성 물질 위 에 표현해서 오랫동안 보존할 수 있게 만든 영상으로 19세 기에 만들어진 발명품 중의 하나이다(Stulik and Kaplan, 2013a; 2013b). 사진이 만들어지는 과정을 살펴보면 다음과 같다(Son, 2006). 카메라를 이용하여 촬영하는 순간 필름이 노출되며 잠상(latent image)이 형성된다. 이 후 필름을 현상 처리(현상-정지-정착-수세)하면 네거티브 이미지가 생기 고, 이를 인화지에 인화 처리(print, 현상-정지-정착-수세)하 여 최종적인 사진이 나오게 된다. 즉 현상된 필름은 네거티 브(negative)이고 사진의 원판이 되며, 프린트 작업을 통해 광선이 사진 네거티브를 통과해서 인화지를 노출시키고, 노출에 의해 잠상이 형성된 인화지를 현상액에 담그면 유 제 안에 들어있는 할로겐화은( $\mathrm{AgX}$, 감광 물질)이 금속은으 로 변하는 화학 작용이 일어난다. 정지액은 현상 작용의 진행을 멈추게 하고 정착액은 광선에 노출되지 않은 나머 지 할로겐화은을 씻어내는 역할을 한다. 마지막으로 수세 해서 건조시키면 사진이 완성된다(London et al., 2013).

사진은 1871년에 리처드 메덕스(Richard Leach Maddox) 에 의해 실버 젤라틴 유제가 개발되어 상용화되면서 대중 화가 되었다. 인화지는 크게 흑백 인화지와 컬러 인화지로 나눌 수 있다. 또한 감광유제의 콘트라스트, 종이의 코팅, 두께, 색깔, 인화의 색조, 광택의 정도, 표면 가공, 용도 등 에 따라 다양하게 구분되며(Lee and Park, 1990), 이에 따른 물리적 특성도 다양하다. 기본 구조는 지지체, 바리타, 바 인더, 표면보호층 등 4 개의 층으로 구성되어 있다(Kang, 2001; Weaver, 2008; Stulik and Kaplan, 2013a).

첫번째 층은 지지체로 초창기에는 비목재섬유를 사용 하여 만든 종이를 사용하였다. 기술이 발달하면서 1 차 세 계대전 이후 철이나 리그닌 등의 불순물을 정제할 수 있게 되자 목재 펄프가 주로 사용되었다. 70 년대 이후 지지체는 종이의 양면에 식물성 수지나 폴리에틸렌 수지를 코팅한 로진 종이(Rosin coated paper)로 대체되었다(Lee and Park, 1990). 두번째 층은 바리타층으로 주로 젤라틴과 황산바륨 $\left(\mathrm{BaSO}_{4}\right)$ 으로 만든 백색코팅제이다. 초기에는 종이에 바인더 만으로 코팅하여 사용되다가 1884년에 바리타 코팅이 개발 되어 상용화 되었다. 바리타층은 거친 지지체의 상부를 덮 고 부드러운 표면을 만들므로 바인더 코팅을 유리하게 한다.

세번째 층은 감광 물질(할로겐화은)이 포함된 바인더층 이다. 바인더는 감광제가 인화지로 스며들지 않게 하고 지 지체 위에 감광 물질이 잘 도포되어 접착하는 역할을 한다. 바인더 재료는 젤라틴이나 알부민이 사용되었으나 젤라틴 이 이상적인 사진 바인더 재료로 정착되었다(Kang, 2001).
네번째 층인 표면보호층은 얇은 젤라틴으로 마찰에 의 한 바인더의 표면 손상을 방지하는 역할을 한다. 표면보호 층은 셀락(shellac)계 바니쉬, 밀랍계 바니쉬 등으로 코팅처 리하여 마무리되기도 한다(Stulik and Kaplan, 2013a).

사진은 예술작품, 역사적 사실이나 경험의 중요한 기록 물로서 보존적 가치를 지닌다. 인공적인 산물이지만 사진 에 사용된 재료들의 변형과 노화는 피할 수 없다. 시간이 지나면서 온·습도 변화에 따른 물리적 손상, 빛, 산, 대기 오염에 따른 화학적 손상, 생물이나 곰팡이 세균에 의한 생물학적 손상, 포장과 액자 제작 재료에 따른 2차 손상 등이 복합적으로 일어난다(Park, 2017). 특히 복합 재질의 근대기록물인 사진은 적절한 보존 환경을 유지하거나 보 존처리를 통하여 수명을 최대한 연장시킬 수 있다(Kang, 2010; Kim et al., 2016) . 이를 위해서는 우선 사진 재질에 대한 과학적 조사가 선행되어야 할 것이다.

본 연구에서는 보로부두르 흑백 사진에 대한 과학적 분 석을 통해 흑백 사진의 재료적 특성을 살펴보고자 한다. 현미경을 이용하여 단면을 관찰하고 사진인화지의 구조적 특징을 조사하였다. 또한 사진에 사용된 재료의 성분분석 을 실시하여 얻은 결과를 바탕으로 향후 흑백 사진의 보존 연구를 위한 기초 자료로 활용하고자 한다.

\section{2. 연구 대상 및 방법}

\section{1. 연구 대상}

연구대상은 인도네시아 문화교육부 보로부두르 보존처

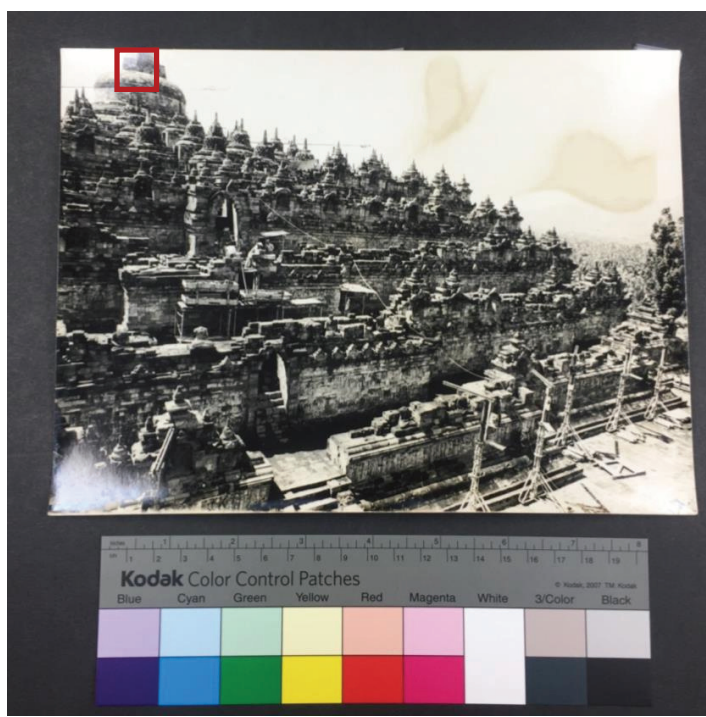

Figure 1. Sampling position of the black and white photograph. 
리소에서 1973년에 촬영한 보로부두르 사원의 흑백 사진 이다. 전체 크기는 가로 $23.1 \mathrm{~cm} \times$ 세로 $17.3 \mathrm{~cm}$ 이며, 사진 표면에는 황색 얼룩이 2군데 나타나 있다. 사진 제공 기관 의 허락하에 사진 상단에서 시편을 채취하여 분석을 진행 하였다(Figure 1).

\section{2. 연구방법}

흑백 사진의 주요 구성 성분을 확인하기 위하여 에너지 분 산형 미소부 X-선형광분석기(X-ray fluorescence spectrometer, $\mathrm{XRF}$ (Eagle 3-XXL, EDAX Inc., USA)를 이용하였다. 분석 조건은 Rh Target, $40 \mathrm{kV}, 600 \mu \mathrm{A}$, spot size $300 \mu \mathrm{m}$ 이며, 분석 환경은 경원소 분석에 적합한 진공상태에서 실시하 였다. 또한 화합물의 결정구조는 다목적고분해능 X-선회 절기(X-ray diffractometer, XRD)(Empyrean, PANanlytical, $\mathrm{NLD)}$ 를 이용하여 분석하였으며, High resolution Pixel 3D-256ch Detector와 $\mathrm{Cu}$ Target을 이용하여 $40 \mathrm{kV}, 40 \mathrm{~mA}$, $5 \sim 80^{\circ}$ 까지 분석하였다.

또한 사진의 표면 상태 조사와 지지체 섬유 식별을 위하 여 광학현미경(optical microscope, OM)(Axiotech 100HD/ Progress 3012, Carl Zeiss, DEU)을 이용하였다. 사진 시편은 에폭시 수지에 마운팅 한 후, 연마지와 광택지를 이용하여 표면을 가공한 다음, 마지막 단계에서 초음파 세척기로 세 척한 후 내부 구조를 조사하였다. 사진 단면 관찰과 성분
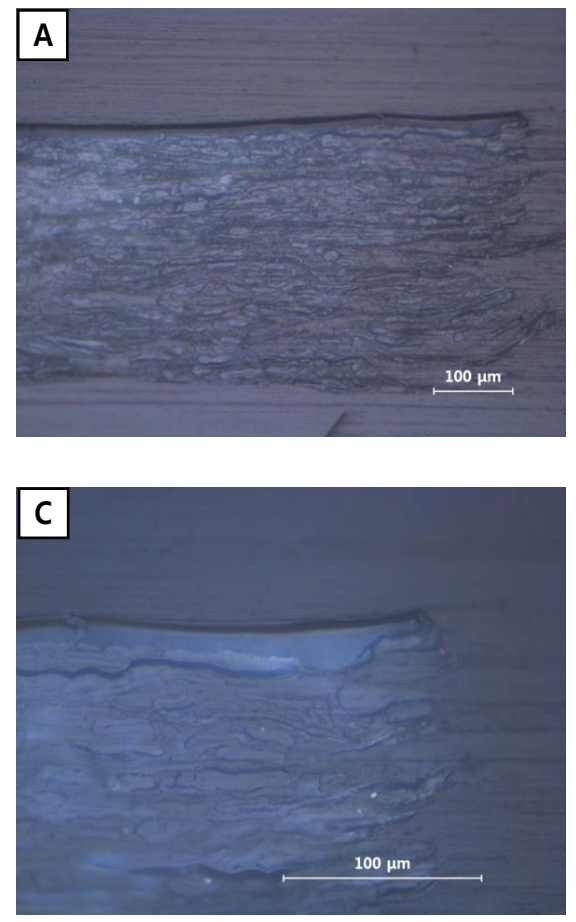

분석을 위하여 주사전자현미경(scanning electron microscope, $\mathrm{SEM}$ (JSM-IT300, Jeol, JPN)과 주사전자현미경에 부착된 에 너지분산형X-선분광기(energy dispersive X-ray spectroscopy, $\mathrm{EDS})\left(\mathrm{X}-\mathrm{MAX}^{\mathrm{N}}\right.$, Oxford, GBR)를 이용하였다. 이때 시료는 백금 $(\mathrm{Pt})$ 으로 $10 \mathrm{~mA}$ 에서 30 초간 코팅하였으며, 분석 조건 은 가속 전압 $10 \sim 15 \mathrm{kV}$, 분석 거리 $10 \mathrm{~mm}$ 이다.

또한 사진의 표면층과 지지체는 적외선분광기(Fouriertransform infrared spectroscopy, FTIR)(Nicolet iS5, Thermo Fisher Scientific, USA)을 이용하여 분석하였다. 분석 조건 은 다이아몬드 크리스탈을 장착하여 감쇠전반사법 (attenuated total reflection, ATR)으로 진행하였고 스캔 횟수 32 회, 분해능 $4 \mathrm{~cm}^{-1}$, 측정범위는 $600 \sim 4000 \mathrm{~cm}^{-1}$ 이다.

\section{3. 연구 결과 및 고찰}

\section{1. 미세구조 관찰}

흑백 사진 단면을 광학현미경과 전자현미경으로 관찰 한 결과 4 개의 층이 확인되었다(Figure 2). 먼저 지지체는 섬유질로 구성되어 있으며 두께는 약 $0.31 \mathrm{~mm}$ 이다(Figure $2 \mathrm{~A} \sim \mathrm{C})$. 바리타층은 $1 \mu \mathrm{m}$ 미만은 작은 입자들로 구성되어 있으며 표면이 매끄럽지 않은 섬유질을 덮고 있는데 두께 가 약 7 26 $\mu \mathrm{m}$ 로 일정하지 않다(Figure 2D, E). 그 위에 바인더로 추정되는 층이 관찰되는데 전자현미경 조사 결
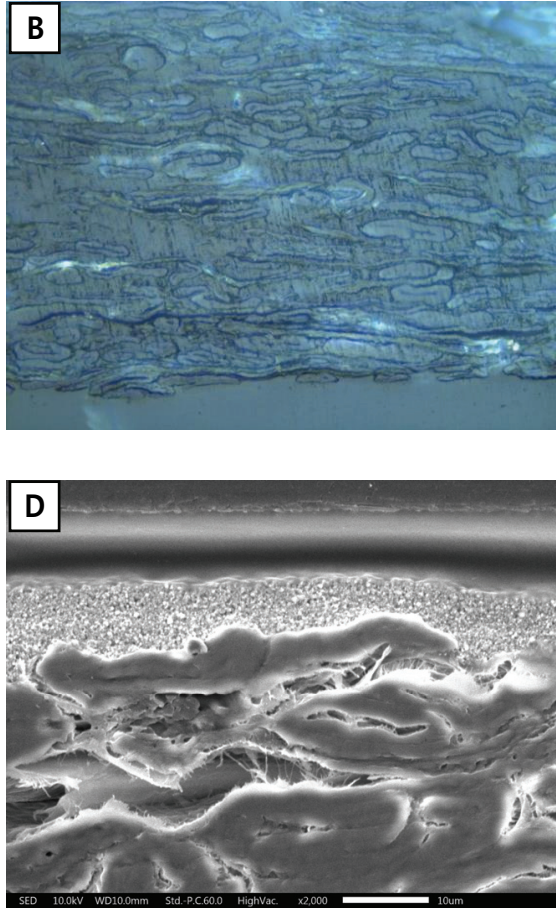

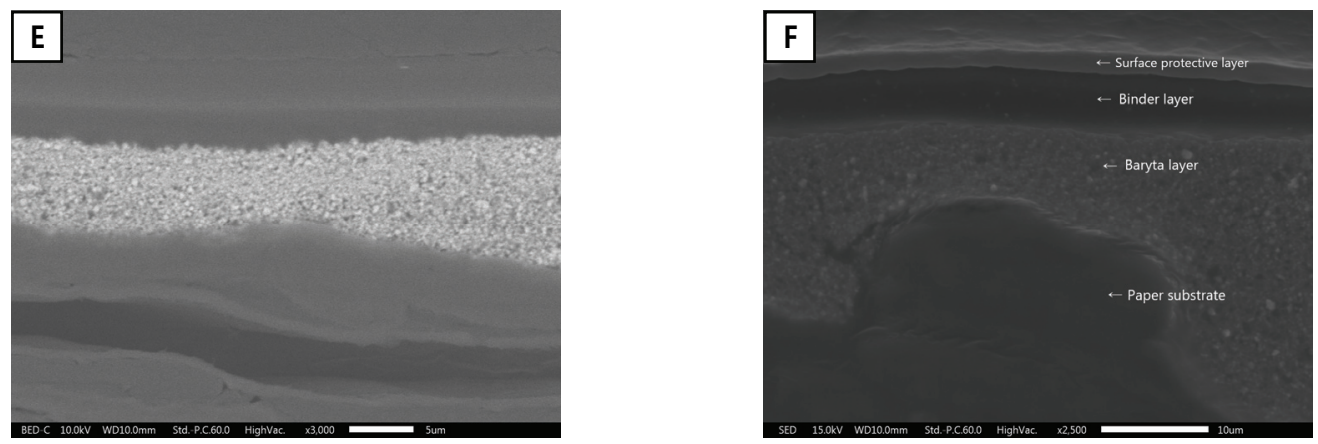

Figure 2. Cross section of black and white photograph. (A), (B), (C) OM, (D), (E), (F) SEM.

과 밀도 차이로 인해 2개의 층으로 구분되는 것을 알 수 있었다(Figure $2 \mathrm{~F}$ ). 감광 물질이 포함된 바인더와 이를 보 호하는 표면보호층으로 여겨지며, 두께는 약 $5 \mu \mathrm{m}, 2 \mu \mathrm{m}$ 이다.

\section{2. 성분 분석}

흑백 사진 표면에 대해 $\mathrm{X}$-선형광분석기와 $\mathrm{X}$-선회절분 석기로 성분과 화합물을 분석하였다. 또한 사진 단면 층위 별 구성 성분은 SEM-EDS를 이용하여 분석하였다. 그 결과 표면의 흑색과 흰색 부분에서는 주성분으로 바륨 $(\mathrm{Ba})$, 황 (S), 은(Ag)이 검출되었다(Figure 3). XRD 분석 결과에서는 흑색 부분에서 황산바륨 $\left(\mathrm{BaSO}_{4}\right)$ 과 산화은 $\left(\mathrm{Ag}_{2} \mathrm{O}\right)$ 이 함께 동정되었고 흰색 부분에서는 황산바륨만 동정되었다

(Figure 4).

SEM-EDS를 이용하여 흑백 사진 단면을 관찰하면서 표 면보호층, 바인더층, 바리타층의 성분을 분석하였다(Table 1, Figure 5). 각 층위별로 동일한 조건으로 분석하여 얻은 성 분 함량을 비교한 결과 표면보호층은 주성분이 탄소(C), 질 소(N), 산소(O)로 확인되었으며 유기물로 추정된다. 바인

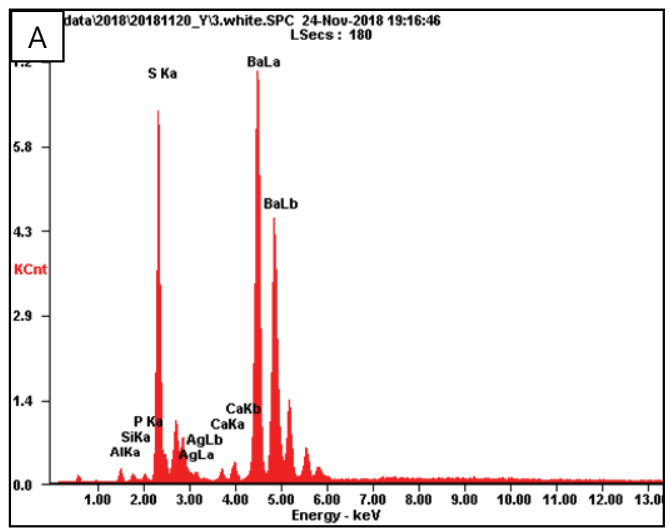

Figure 3. XRF spectrum of black and white photograph. (A) Black part of photograph, (B) White part of photograph.

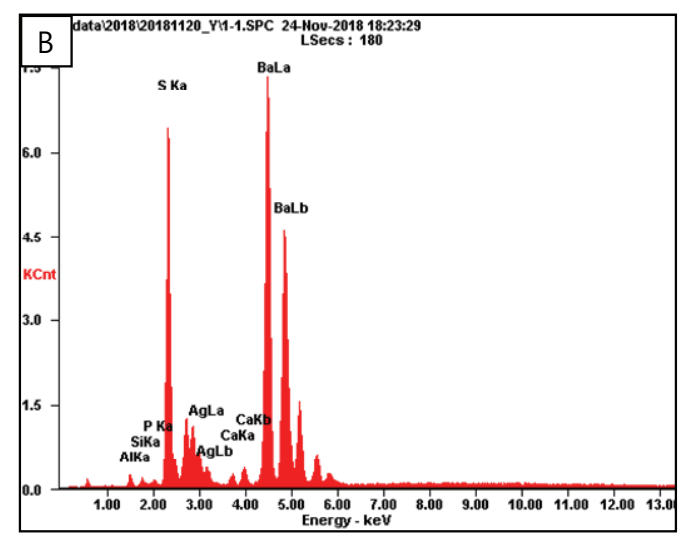

더층은 탄소, 질소, 산소, 은 $(\mathrm{Ag})$ 등이 확인되었으며 은은 $24.28 \mathrm{wt} \%$ 로 다른 층에 비해 높게 검출되었다. 일반적으로 흑백 사진 인화지의 바인더 층은 할로겐화은을 분산시킨 젤라틴 유제로, 프린트 작업을 거치면서 빛에 노출된 부분 은 할로겐화은이 은염(silver salt)으로 바뀌게 되어 흑색으 로 나타나고 노출되지 않은 할로겐화은은 은염이 생성되지 않은 체 제거된다. 따라서 은의 함량이 표면보호층보다 바 인더층에서 높게 검출된 것은 은염이 생성된 부분이거나 할로겐화은이 모두 제거되지 않고 남아있는 것으로 판단된 다. 이러한 결과는 표면의 XRF 분석 결과에서 표면 흑색과 백색 모두 은이 검출된 점, XRD 결과에서 산화은이 검출된 점을 통해 할로겐화은의 영향으로 추정해 볼 수 있다. 또한 표면층과 바인더 층에서 염소 $(\mathrm{Cl})$ 가 검출되고 있는 것은 염 화은 $(\mathrm{AgCl})$ 바인더의 가능성을 추정해 볼 수 있었다.

바리타층은 탄소, 질소의 함량은 상대적으로 낮으나 바 륨 $(\mathrm{Ba})$, 산소 $(\mathrm{O})$, 황 $(\mathrm{S})$ 의 함량이 높게 검출되었다. 앞서 $\mathrm{XRD}$ 분석 결과에서 황산바륨이 흑색과 백색 부분에서 모 두 동정된 것은 바리타층의 황산바륨이 측정된 것을 확인 할 수 있었다. 


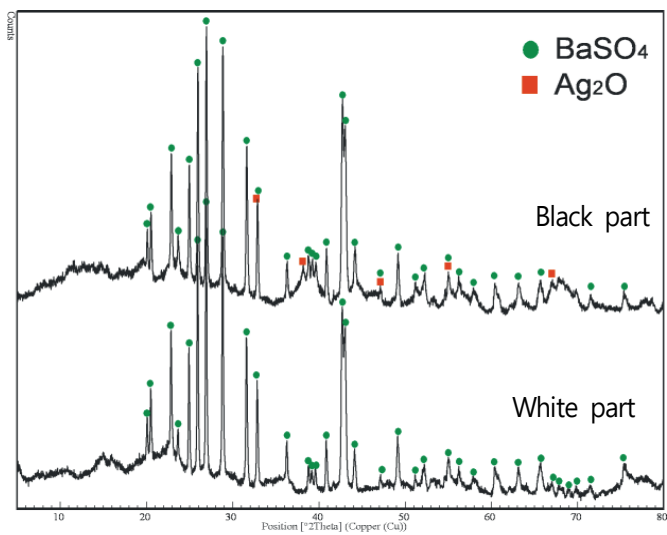

Figure 4. XRD patterns of black and white photograph.
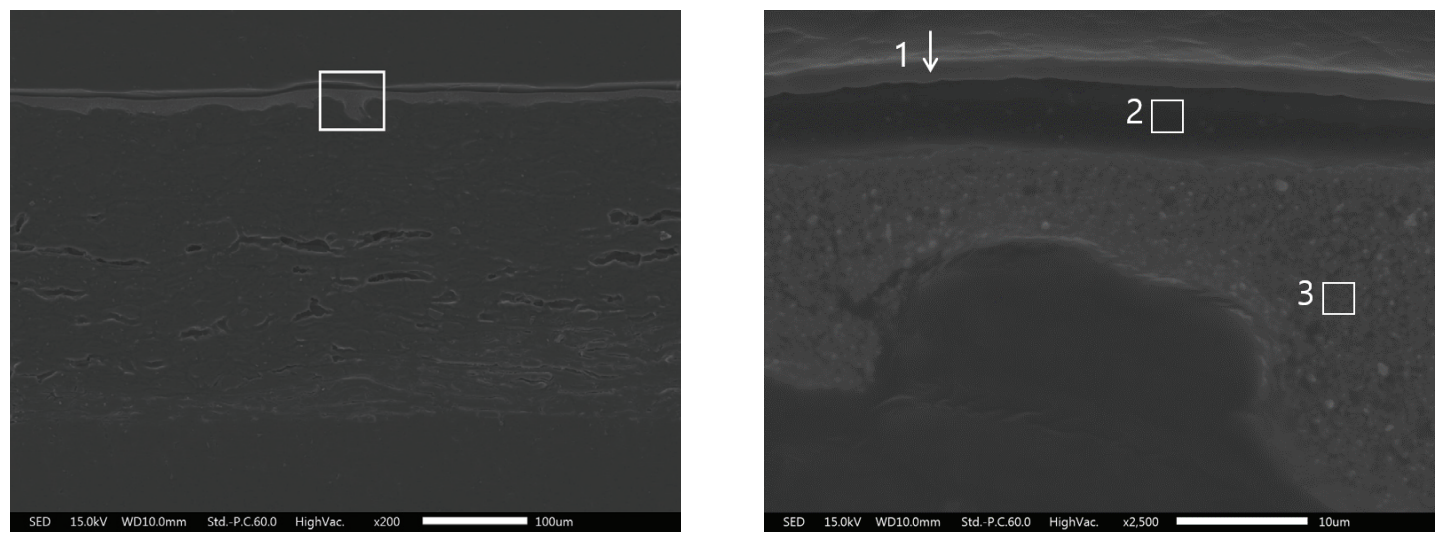

Figure 5. SEM image(left) and position of EDS analysis(right) of black and white photograph.

Table 1. EDS results of black and white photograph

\begin{tabular}{|c|c|c|c|c|c|c|c|c|c|c|}
\hline \multirow{2}{*}{ Position } & \multicolumn{10}{|c|}{ Major element (wt\%) } \\
\hline & $\mathrm{C}$ & $\mathrm{N}$ & $\mathrm{O}$ & $\mathrm{Al}$ & $\mathrm{Si}$ & S & $\mathrm{Cl}$ & $\mathrm{Ca}$ & $\mathrm{Ag}$ & $\mathrm{Ba}$ \\
\hline 1 & 37.83 & 27.07 & 25.27 & 0.13 & 0.20 & 2.48 & 2.56 & 0.56 & 2.09 & 2.73 \\
\hline 2 & 26.82 & 13.39 & 11.25 & 1.20 & 1.24 & 4.68 & 1.25 & 7.84 & 24.28 & 8.05 \\
\hline 3 & 7.01 & 7.01 & 27.58 & 0.16 & - & 11.68 & 0.20 & 0.28 & - & 48.66 \\
\hline
\end{tabular}

\section{3. 재질 분석}

흑백 사진의 표면보호층과 지지체를 광학현미경과 전 자현미경으로 관찰했으며, 적외선분광기를 이용하여 성분 분석 하였다. 또한 지지체에서 섬유편을 채취하여 섬유의 단면과 측면의 형태를 광학현미경을 이용하여 조사하였 다. 사진의 표면보호층에는 요철이 관찰되는데 이는 반사 도를 낮추는 역할을 하는 것으로 여겨진다(Figure 6A). 지 지체에서는 섬유가 그대로 드러나 있으며 지지체를 보호
하기 위한 처리는 없는 것으로 보인다(Figure $6 \mathrm{~B}, \mathrm{C}$ ). 표면보호층과 지지체의 적외선 스펙트럼은 Figure 7에 나타내었다. 표면보호층의 적외선 스펙트럼을 보면 N-H-O 신축진동과 관련된 $3200 ~ 3000 \mathrm{~cm}^{-1}$ 밴드, C-H 신축진동과 관련된 3100 2800 $\mathrm{cm}^{-1}$ 밴드, 아미드 I 과 관련된 $1630 \mathrm{~cm}^{-1}$ 밴드, 아미드 $\Pi$ 와 관련된 $1538 \mathrm{~cm}^{-1}$ 밴드 등이 확인되었고 이와 같은 결과는 단백질 물질의 특성을 보여주고 있으며 젤라틴의 스펙트럼과 거의 일치하고 있다(Derrick et al., 1999). 또한 밀랍이나 수지 등을 사용한 표면처리 관련 물 
질의 피크는 확인되지 않았다.

지지체의 적외선 스펙트럼을 보면 $\mathrm{O}-\mathrm{H}$ 신축진동에 해 당하는 $3600 ~ 3200 \mathrm{~cm}^{-1}$ 밴드, C-H 신축진동과 관련된 $31002800 \mathrm{~cm}^{-1}$ 밴드, $\mathrm{O}-\mathrm{H}$ 굽힘 진동과 관련된 $1643 \mathrm{~cm}^{-1}$ 밴드, C-H 굽힘 진동과 관련된 $1480 ~ 1300 \mathrm{~cm}^{-1}$ 밴드, C-O 신축진동과 관련된 1300 900 $\mathrm{cm}^{-1}$ 밴드 등이 확인되었다

(Figure 7B). 이와 같은 스펙트럼 패턴은 셀룰로오스의 스
펙트럼과 유사한 것으로 판단된다.

지지체 섬유의 단면과 측면을 광학현미경으로 관찰하 였다(Figure 8). 단면은 끝이 둥근 타원형이고 가운데에 긴 형태의 중공이 관찰되었다. 측면은 길이방향으로 줄무늬 가 있고, 단층과 교차 무늬가 나타나고 있어 마섬유의 특징 으로 판단된다(The National Folk Museum of Korea, 2005).
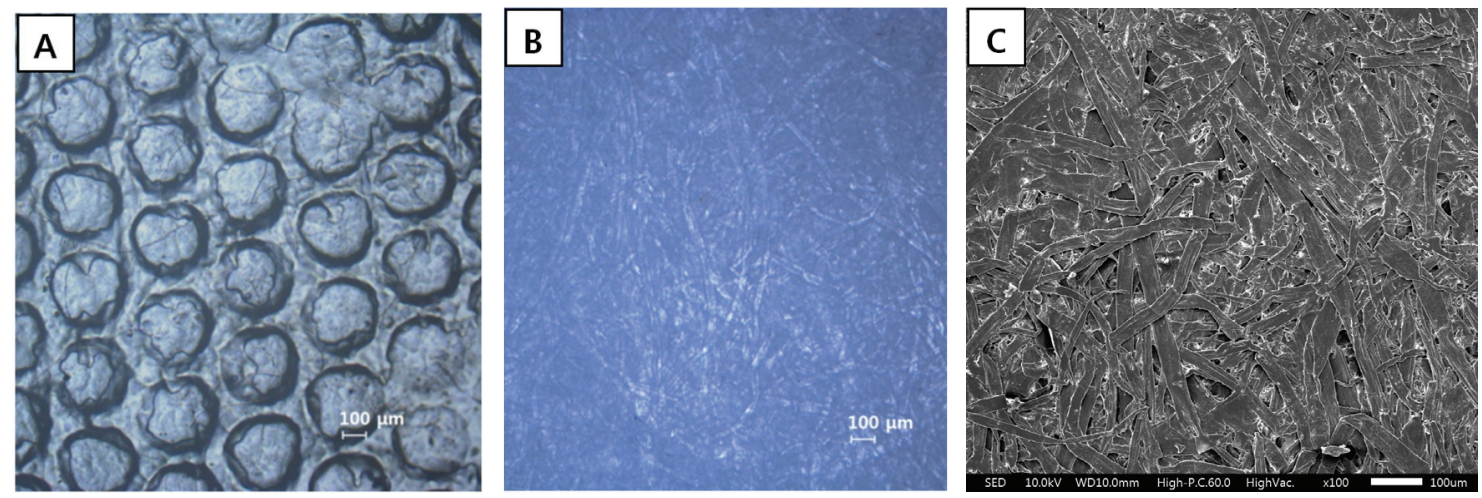

Figure 6. Microscope images. (A) $\mathrm{OM}$ of $\operatorname{surface}(\times 50)$, (B) $\mathrm{OM}$ of paper substrate $(\times 50)$ and $(\mathrm{C})$ SEM image of paper substrate.
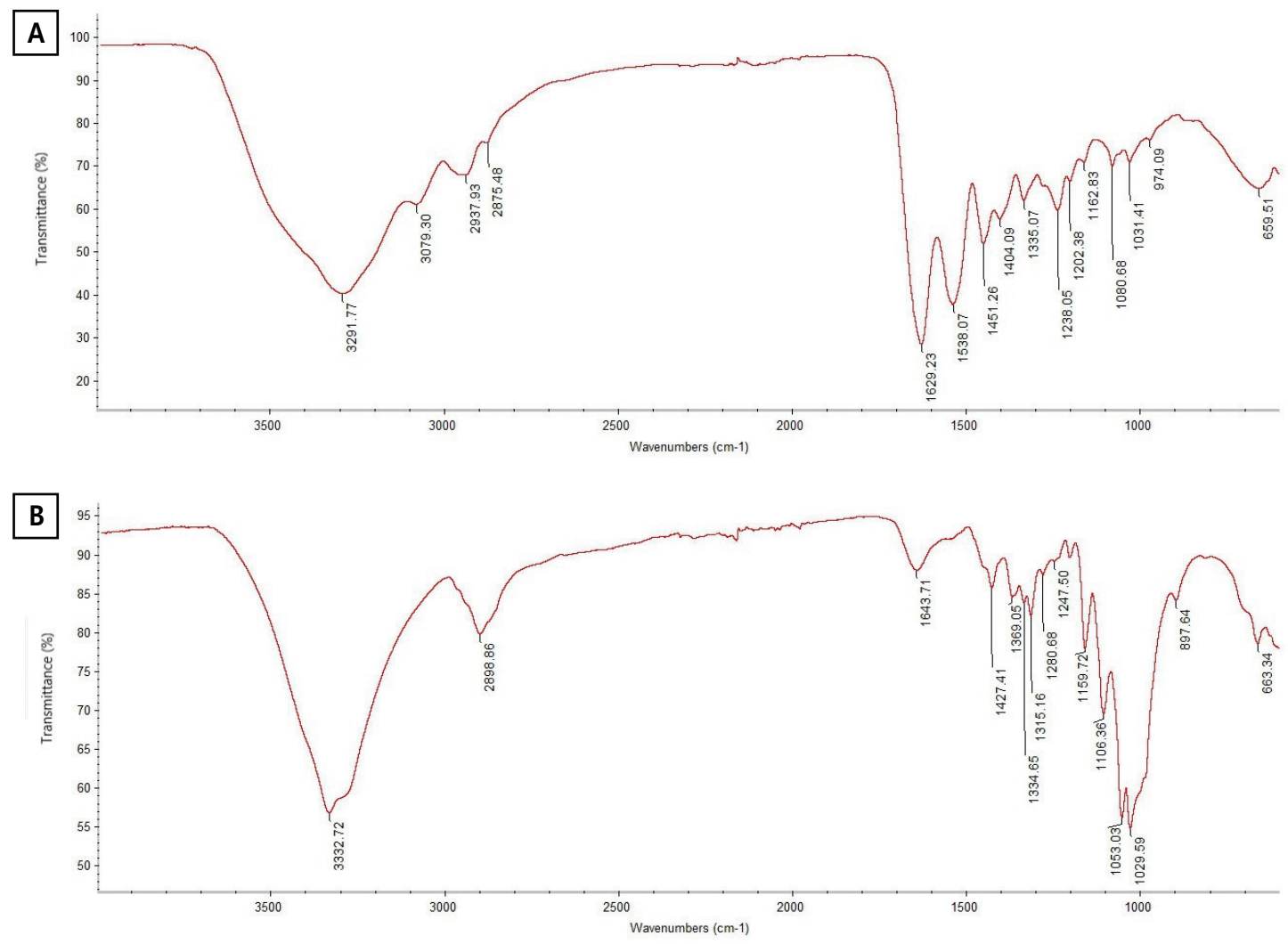

Figure 7. ATR-FTIR spectra of black and white photograph. (A) Surface, (B) Paper substrate. 

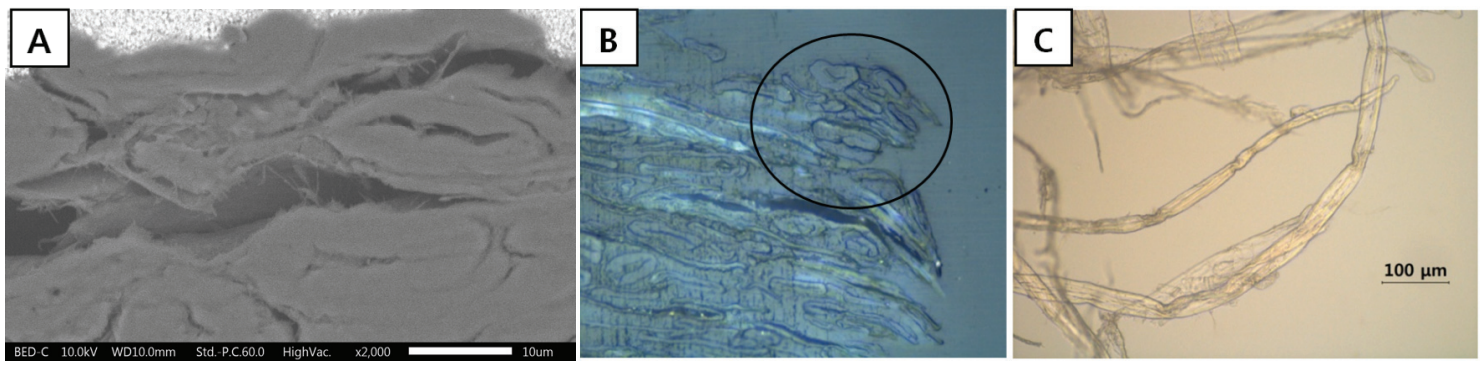

Figure 8. Microstructure of fiber in paper substrate. (A) SEM image, (B, C) OM image.

\section{4. 결 론}

이 연구에서는 인도네시아 보로부두르 흑백 사진의 과 학적 분석을 통해 사진의 재료적 특성을 확인하고자 하였다. 보로부두르 흑백 사진은 4 개의 층으로 구성되어 있다. 지지체는 셀룰로오스 기반의 종이로 마섬유를 사용하여 제 작된 것으로 여겨지며 바리타층은 작은 입자 상태의 황산 바륨으로 지지체를 덮고 있다. 바인더층에서는 화상이 만 들어진 부분에서 산화은이 검출되나 빛에 노출되지 않은 부 분은 정착과정에서 할로겐화은이 모두 제거되지 않고 바이 더 층이나 표면보호층에 남아 있는 것으로 추정되었다. 또한 표면보호층은 코팅처리가 되지 않은 젤라틴으로 요철을 주 어 표면에서 반사되는 광선이 산란되도록 처리하였다.

이번 조사에서는 흑백 사진에서 시료를 채취하여 분석 을 진행하였지만 표면층에 대한 XRF와 XRD 분석을 통해 내 부 물질의 성분을 확인할 수 있었고, 지지체와 표면보호층 재 료에 대한 특성을 파악할 수 있었던 점으로 보아 비파괴분 석으로 사진 재료의 특성을 파악할 수 있을 것으로 판단된다.

일반적으로 흑백 사진(black and white print) 또는 섬유 기반 젤라틴 실버 사진(fiber base gelatin silver print)으로 불 리는 형태의 사진은 20 세기 발명품으로, 현재에도 생산되고 있다. 사진 재료상에서 인화지의 감광유제의 콘트라스트, 종이의 코팅, 두께, 인화 색조, 광택의 정도, 표면 가공, 용도 등에 따라 수많은 종류의 인화지가 판매되고 있다(Lee and Park, 1990). 이처럼 사진은 인화지의 종류에 따라 구성 재료 가 다르기 때문에 프린터 작업 당시 사용한 인화지의 특성에 대한 기록이 없다면 과학적 분석을 통한 기초적인 재질 조 사가 필요하다. 이러한 데이터의 축적은 앞으로 사진의 보 존처리 및 보관을 위한 기초 자료로 활용될 수 있을 것이다.

\section{사 사}

본 연구는 문화재청 국립문화재연구소 문화유산 조사 연구(R\&D) 사업의 지원을 받아 수행되었다.

\section{REFERENCES}

Derrick, M.R., Stulik, D. and Landry, J.M., 1999, Infrared spectroscopy in conservation science. The J. Paul Getty Trust, Los Angeles, 179-200.

Kang, D.I., 2010, The modern cultural heritage value and conservation of documentary art records. Journal of Conservation Science, 26(1), 69-76. (in Korean with English abstract)

Kang, S.J., 2001, A study on photographic printing using zoological protein (Focused on the usage of salted paper). Master's thesis, Sangmyung University, Seoul. (in Korean with English abstract)

Kim, S.C., Park, J.H., Jang, H.U., Choi, J.W. and Ahn, J.Y., 2016, Conservation treatment of modern cultural heritage rickshaw. Journal of Conservation Science, 32(2), 203-213. (in Korean with English abstract)

Lee, B.H. and Park, J.U., 1990, Introduction photographic technology. Haetteum, Seoul, 264-303. (in Korean)

London, B., Stone, J. and Upton, J., 2013, Photography (Kim, S.G., trans). Seoul, 13, 109-125. (Original work published 2013) (in Korean)

Park, S.H., 2017, Conservation methods of photographic works. Journal of the National Museum of Modern and Contemporary Art, Korea, 9, 79-91. (in Korean with English abstract)

Son, Y.H., 2006, Zone system for digital photography. Ph.D. dissertation, Chung-ang University, Seoul, 10-14. (in Korean with English abstract)

Stulik, D.C. and Kaplan, A., 2013a, Silver gelatin. The J. Paul Getty Trust, Los Angeles, 4-63.

Stulik, D.C. and Kaplan, A., 2013b, Salt print. The J. Paul Getty Trust, Los Angeles, 4-18.

The National Folk Museum of Korea, 2005, Identification of natural fiber \& fur, Atlas. The National Folk Museum of Korea, Seoul, 33-41. (in Korean)

Weaver, G., 2008, A guide to fiber-base gelatin silver print condition and deterioration. Gawain Weaver and the Advanced Residency Program in Photograph Conservation, 4-7. 